\title{
Tillage Frequency, Soil Compaction and N-Fertilizer Rate Effects on Yield of Teff (Eragrostis Tef (Zucc) Trotter) in Central Zone of Tigray, Northern Ethiopia
}

\author{
Haftamu Gebretsadik ${ }^{1}$, Mitiku Haile ${ }^{2}$ and ${ }^{*}$ Charles F. Yamoah $^{2}$ \\ ${ }^{1}$ Tigray Agricultural Research Institute, Axum Agricultural Research Centre, P.O. Box 230, \\ Axum, Tigray, Ethiopia. \\ ${ }^{2}$ Department of LaRMEP, College of Dry Land Agriculture and Natural Resource Management, \\ Mekelle University, P.O. Box 231, Mekelle, Ethiopia (*yamoahcf@yahoo.com).
}

\begin{abstract}
In Ethiopia, teff is grown for its grain and straw. There is a dearth of information with respect to plowing, compaction and fertilization on vertisols in central zone of Tigray. Therefore, this study was conducted to determine the effects of plowing frequency, soil compaction and $\mathrm{N}$ on teff yields. The experimental design was a split-split plot where main plot was plowing frequency with three levels (once, twice and thrice); sub-plot was compaction with two levels (with and without compaction) and sub-sub plot was $\mathrm{N}$-fertilizer rate with four levels $(0 \mathrm{~kg} \mathrm{~N} / \mathrm{ha}, 46 \mathrm{Kg}$ $\mathrm{N} / \mathrm{ha}, 69 \mathrm{Kg} \mathrm{N} / \mathrm{ha}$ and $92 \mathrm{Kg} \mathrm{N} / \mathrm{ha}$ ). There were three replications. Results showed that plowing frequency had no significant effect on most of the yield components except on tillering when the soil is compacted. Maximum average number of tillers per plant (2.75) was obtained from compacted plots plowed two times. Compaction affected almost all yield and yield components significantly. Higher number of tillers per plant (2.64) from non compacted plots and higher stand cover (about 94\%) from compacted plots were found. In addition, maximum biomass $(4210.617 \mathrm{~kg} / \mathrm{ha})$ and grain $(1221.98 \mathrm{~kg} / \mathrm{ha})$ yields were obtained from compacted plots due to enhanced soil to seed contact resulting in increased plant population. Nitrogen fertilizer significantly increased grain yield and yield components. Maximum stand cover (94.78\%), plant height $(92.16 \mathrm{~cm})$, panicle length $(37.75 \mathrm{~cm})$, biomass yield $(4724 \mathrm{~kg} / \mathrm{ha})$ and grain yield $(1387.9$ $\mathrm{kg} / \mathrm{ha}$ ) were found from plots receiving $92 \mathrm{kgN} / \mathrm{ha}$. Partial budget analysis of $\mathrm{N}$ fertilizer rates indicted that higher marginal rate of return $(525 \%)$ were found by applying $69 \mathrm{~kg} \mathrm{~N} / \mathrm{ha}$. It is recommended that farmers use $69 \mathrm{~kg} \mathrm{~N} / \mathrm{ha}$ so as to get economically feasible returns and yield.
\end{abstract}

Keywords: Compaction, Fertilizer N, Plowing frequency, Teff, Vertisol.

\section{INTRODUCTION}

Tef (Eragrostic teff (zucc.) Trotter) is annual C4 grass that belongs to the family Poacea (Kebede, et al., 1989). The crop exhibits high variability within regions of cultivation and between plants of the same accession (Tadesse, 1993). It is primarily self pollinated and provides naturally inbred lines, though intermittent cross pollination introduces new genetic material to 
existing teff population (Nicole, 1999). Teff is a staple cereal crop in Ethiopia. It is grown both for its grain and straw..

In Ethiopia, teff performs well in 'Weina dega' agro-ecological zones or medium altitude (1700$2400 \mathrm{~m}$ above sea level) (Nicole, 1999; Deckers et al., 1998). According to Deckers et al. (1998), the mean temperature and optimum rainfall during the growing season range from $10^{\circ} \mathrm{C}$ to $27^{\circ} \mathrm{C}$ and 450 to $550 \mathrm{~mm}$, respectively. The length of growing period (LGP) or the number of days to maturity of teff, considering rainfall and evapo-transpiration of 2-6 mm/day ranges from 60 to 180 days (depending on variety and altitude) with an optimum of 90 to 130 days (Deckers et al., 1998).

The first plowing for teff production in most part of the country is done as soon as the previous crop is harvested. In less weed prone areas, it is done after the onset of the small (belg) or main (kiremt) rainy seasons (Fufa et al., 2001). Teff needs high tillage frequencies as compared to other cereal crops in Ethiopia. Also, it requires firm, level seedbed, free from clods and stumps (Deckers et al., 1998). With respect to teff cultivation on Vertisols, several plowings are necessary, occasionally as much as 12 times, relative to Nitosols (Deckers et al., 1998). According to Kenea et al. (2001), the tillage frequency for teff in Ethiopia ranges from 3 times in Nazareth to 12-times in western Wellega. Though research results indicated teff grain yield increased with increasing number of plowings (IAR, 1998). Others recommended tillage frequency for teff to be 3-5 times (Melesse, 2007), 5-9 times especially in high rainfall areas (Tarekegn et al., 1996) and 4-times (Nyssen et al., 2000). Generally, the tillage frequency is not consistent from region to region, from soil type to soil type and from farmer to farmer. This suggests further research on tillage frequency for teff.

Due to shrink-swell characteristics of Vertisols, teff seeds broadcasted on them during sowing need moderate soil compaction to enhance their attachment with the soil. Most teff growing farmers on Vertisols trample their teff seedbed either before planting or soon after; in both occasions using cattle, sheep, goats and/or donkeys (Tadesse, 1969). According to TARI (2007), trampling makes seedbed firm and flat, prevents the soil surface from quick drying, provides a thin coverage of broadcasted seeds, prevents seeds from desiccation and consequently enhances good germination and seedling establishment (TARI, 2007; Fufa et al., 2001). In addition, the results of comparative studies conducted for three years at Debre Zeit (DZARC, 1989) on two soil types (Inceptisol and Vertisol) also revealed that the effect of seedbed trampling by humans 
and oxen on grain yield was not significant except at Chefe Donsa where a significant yield increase was obtained (Fufa et al., 2001). Melesse (2007) reported the necessity of teff seedbed trampling and recommended the use of subsoilers to break hard pans. According to TARI (2007), some farmers in central and North-Western zones of Tigray trample their teff seedbed using human feet when the land is small and there is less availability of animals.

Major factors affecting teff fertilizer recommendation are water logging, seasons of planting, cropping history, lodging and weed growth (Kenea et al., 2001). The actual rate of fertilizer used by farmers is below the blanket recommendation i.e. $100 \mathrm{~kg} \mathrm{DAP} / \mathrm{ha}$ and $100 \mathrm{~kg} \mathrm{urea} / \mathrm{ha}$ set by the Ministry of Agriculture and Rural Development (Kenea et al., 2001). Generally, the recommended rate of fertilizer for teff is 25 to $40 \mathrm{~kg} \mathrm{~N} / \mathrm{ha}$ and 30 to $40 \mathrm{~kg} \mathrm{P}_{2} \mathrm{O}_{5} /$ ha on light soils such as Nitosols, Luvisols and Cambisols, and 50-60kg N/ha and 30-35 $\mathrm{kg} \mathrm{P}_{2} \mathrm{O}_{5} /$ ha for heavy soils such as Vertisols (Deckers et al., 1998). Compaction narrows soil pores and reduces water infiltration which result in water logging problem in vertisols. Such water logging causes $\mathrm{N}$ losses by denitrification. Therefore, determining the optimum rate of $\mathrm{N}$ under those agronomic practices is necessary.

\section{MATERIALS AND METHODS}

\subsection{Site description}

The research was conducted in northern Ethiopia, central zone of Tigray, Wereda La'elay Maichew and Tabia Hatsebo. It is $5 \mathrm{~km}$ east of Axum town $\left(38^{0} 34^{\prime}\right.$ and $39^{\circ} 25^{\prime}$ east, and $13^{0} 15^{\prime}$ and $14^{0} 39^{\prime}$ north). Altitude is of $2050 \mathrm{~m}$ and classified as sub humid agro-ecology where most of the middle altitude crops such as teff, wheat, Fababean are commonly grown. The rainfall ranges from 300 to $800 \mathrm{~mm} /$ annum. The major arable crop in the area is teff that is mostly widely distributed soil type in the area.

\subsection{The experimental design}

A split-split plot design with three replications was used. The main factor was three plowing frequencies (once, twice and thrice); the sub factor was two compaction levels (with and without compaction) and the sub-sub factor was four rates of $\mathrm{N}$ - fertilizer $(0 \mathrm{kgN} / \mathrm{ha}$ (control), $46 \mathrm{~kg} \mathrm{~N} / \mathrm{ha}$, $69 \mathrm{~kg}$ N/ha and $92 \mathrm{~kg} \mathrm{~N} / \mathrm{ha}$ ). The teff variety DZ-01-974 (Dukem) was used and sown at a rate of $30 \mathrm{~kg} / \mathrm{ha}$. Treble Super Phosphate (TSP) was used as a source of P and applied uniformly to all plots at rate of $60 \mathrm{~kg} \mathrm{P}_{2} \mathrm{O}_{5} /$ ha (a national recommendation of $\mathrm{P}$ for teff grown on vertisols). 
Those plots, which received three plowing frequencies, were plowed first at the beginning of the cropping season; second two months after and the third at sowing. The plots, which received two plowing frequencies, were plowed first, at the beginning of the season and at sowing. The plots, which received one plowing, were plowed only at sowing.

Sub plots were compacted by trampling with human labor soon after sowing and broadcasting urea and TSP fertilizers. The $\mathrm{N}$ fertilizer rates were applied to the sub-sub plots of each compacted and non-compacted plots, half at sowing and the rest at top dressed at time of the crop tillering (i.e. one month after sowing). Penetrometer resistance was measured for each sub plots at sowing $(0-30 \mathrm{~cm})$ soil depth. Penetrometer readings were recorded at $5 \mathrm{~cm}$ interval along the soil depth. Bulk density was determined by the core sample approach.

Stand percentage, which refers to the percentage of the plot area covered by teff seedlings, was estimated when the teff seedlings reach three to four leaves age. Plant height, panicle length and tillering potential were measured by randomly selecting 10 plants per plot. Both biomass and grain yields were measured after sun drying for one week. Harvest index (HI) was calculated by the formula defined by Fleischer et al. (1989):

\section{$H I=\underline{\text { Grain yield }(\mathrm{kg} / \mathrm{ha})} \times 100$ \\ Total biomass yield (kg/ha)}

\subsection{Partial Budget Analysis}

Variable cost of $\mathrm{N}$ fertilizer was largely used for partial budget analysis. Price fluctuations during the production season were considered. Marginal Rate of Return, which refers to net income obtained by incurring a unit cost of fertilizer, was calculated by dividing the net increase in yield of teff due to the application of each rate to the total cost of $\mathrm{N}$ fertilizer applied at each rate. This enables us to identify the optimum rate of $\mathrm{N}$ fertilizer for teff production.

\section{RESULTS AND DISCUSSION}

\subsection{Penetration Resistance and Bulk Density}

There is no significant difference in penetration resistance between compacted and noncompacted plots as well as within each soil depth in both plots. The average penetration resistance $(\mathrm{MPa})$ in both compacted and non-compacted plots is 0.83 and 0.77 , respectively. Maximum penetrometer resistance is observed at soil depth of $10-15 \mathrm{~cm}$ in compacted and 20- 
$25 \mathrm{~cm}$ in non-compacted plots. Ehlers et al. (1983) indicated that a penetrometer resistance of 3.6 $\mathrm{MPa}$ and above under tilled field could impede root growth of oats which is similar to root system of teff. In addition, any penetrometer resistance over $2.0 \mathrm{MPa}$ can significantly reduce root growth and development (Ishaq et al., 2001; Oussible et al., 1992). Therefore, the average penetration penetrometer from the compacted plots of $0.83 \mathrm{MPa}$ is lower than the values mentioned in the literature. This means compaction of the plots does not affect the root penetration of teff. However, there is slight change in bulk density of both plots, $0.79 \mathrm{~g} / \mathrm{cm}^{3}$ in non-compacted plots against $0.98 \mathrm{~g} / \mathrm{cm}^{3}$ in compacted plots.

Table 1. Main effects of plowing frequency, compaction and $\mathrm{N}$-fertilizer rates on tillering potential and stand cover.

\begin{tabular}{|l|l|l|}
\hline Factors & $\begin{array}{l}\text { Tillering potential } \\
\text { (tiller/plant) }\end{array}$ & Stand percentage \\
\hline Plowing frequency & & \\
\hline P1=once & 2.33 & 90.75 \\
\hline P2=twice & 2.67 & 91.25 \\
\hline P3=thrice & 2.38 & 92.208 \\
\hline SE & 0.116 & 1.500 \\
\hline LSD & $\mathrm{ns}$ & Ns \\
\hline CV (\%) & 18.77 & 3.55 \\
\hline compaction & & \\
\hline Non compacted & $2.64^{\mathrm{a}^{*}}$ & $88.56^{\mathrm{b}}$ \\
\hline Compacted & $2.28^{\mathrm{b}}$ & $94.25^{\mathrm{a}}$ \\
\hline SE & 0.094 & 0.520 \\
\hline LSD & 0.259 & 5.374 \\
\hline CV (\%) & 18.77 & 3.55 \\
\hline $\mathbf{N}-\mathrm{fertilizer} \mathrm{rate}$ & & \\
\hline $0 \mathrm{kgN} / \mathrm{ha}$ & 2.28 & $83.06^{\mathrm{c}}$ \\
\hline $46 \mathrm{kgN} / \mathrm{ha}$ & 2.50 & $92.72^{\mathrm{b}}$ \\
\hline $69 \mathrm{kgN} / \mathrm{ha}$ & 2.67 & $95.06^{\mathrm{a}}$ \\
\hline $92 \mathrm{kgN} / \mathrm{ha}$ & 2.40 & $94.78^{\mathrm{ab}}$ \\
\hline SE & 0.134 & 0.735 \\
\hline LSD & $\mathrm{ns}$ & 3.441 \\
\hline CV (\%) & 18.77 & 3.55 \\
\hline
\end{tabular}

*Means not connected by the same letters are significantly different at alpha 0.05. 


\subsection{Yield and yield component}

\subsubsection{Stand cover and Tillering}

Plowing frequency did not show any significant effect on tillering potential, and stand cover of teff. However, compaction has significant effect on these yield attributes. This may be due to its influence on absorption of nutrients and moisture by the crop. Relatively, higher stand cover were found from compacted plots but higher average number of tiller per plant was found from non compacted plots. The higher stand cover from the compacted plots is due to the good attachment of teff seeds with the soil which might have resulted in efficient use of nutrients and moisture as well as improved germination. Except in stand cover, the three N-fertilizer rates did not show significant difference from the control in number of tillers per plant. Highest stand cover (95\%) was obtained from application of $69 \mathrm{~kg} \mathrm{~N} / \mathrm{ha}$.

Interaction of plowing frequency and compaction significantly affect tillering potential of teff (Table.1). Relatively higher number of tillers per plant ( $\sim 3$ tillers/plant) was found from plots plowed two times and compacted than the others (Table 2). In addition, interaction of compaction with $\mathrm{N}$ rates significantly affect tillering because compaction enables teff plants to properly utilize the applied $\mathrm{N}$ fertilizer (Table 3 ).

Table 2. Interaction effect of plowing frequency and compaction on tillering potential of teff.

\begin{tabular}{|l|l|l|l|}
\hline \multirow{2}{*}{ Compaction } & \multicolumn{3}{|l|}{ Plowing frequencies } \\
\cline { 2 - 4 } & P1 & P2 & P3 \\
\hline C0 & $2.67^{\mathrm{ab}^{*}}$ & $2.58^{\mathrm{ab}}$ & $2.67^{\mathrm{ab}}$ \\
\hline C1 & $2.00^{\mathrm{b}}$ & $2.75^{\mathrm{a}}$ & $2.08^{\mathrm{ab}}$ \\
\hline
\end{tabular}

*Means not connected by the same letters are significantly different at alpha 0.05.

Where: $\mathrm{P} 1$ = plowing first, $\mathrm{P} 2=$ plowing twice, $\mathrm{P} 3=$ plowing thrice, $\mathrm{C} 0=$ non-compacted plots and $\mathrm{C} 1=$ compacted plots, $\mathrm{LSD}_{0.05}=0.575, \mathrm{SE}=0.163, \mathrm{CV}(\%)=18.8$ 
Table 3. Interaction effect of compaction and $\mathrm{N}$-fertilizer rate on tillering potential of teff

\begin{tabular}{|l|l|l|}
\hline \multirow{2}{*}{$N$-rate (kgN/ha) } & \multicolumn{2}{|c|}{ Compaction } \\
\cline { 2 - 3 } & Non Compacted & Compacted \\
\hline 0 & $2.56^{\mathrm{ab}}$ & $2.00^{\mathrm{b}}$ \\
\hline 46 & $2.44^{\mathrm{ab}}$ & $2.56^{\mathrm{ab}}$ \\
\hline 69 & $2.22^{\mathrm{b}}$ & $3.11^{\mathrm{a}}$ \\
\hline 92 & $2.44^{\mathrm{ab}}$ & $2.33^{\mathrm{ab}}$ \\
\hline
\end{tabular}

*Means not connected by the same letters are significantly different at alpha 0.05.

Where, $\mathrm{LSD}_{0.05}=0.426, \mathrm{SE}=0.190, \mathrm{CV}(\%)=18.8$

Interaction effect of compaction and $\mathrm{N}$ fertilizer on ground cover was significant. Therefore, compaction promotes emergence of teff seedlings through efficient utilization of soil nutrients i.e. the applied $\mathrm{N}$ and moisture. Relatively, greater ground cover was obtained from compacted plots receiving higher $\mathrm{N}$ fertilizer rates (Table 4).

Table 4. Interaction effect of compaction and $\mathrm{N}$-fertilizer rate on stand cover of teff.

\begin{tabular}{|l|l|l|}
\hline \multirow{2}{*}{ N-rate (kgN/ha) } & \multicolumn{2}{|c|}{ Compaction } \\
\cline { 2 - 3 } & Non Compacted & Compacted \\
\hline 0 & $78.33^{\mathrm{d}}$ & $87.78^{\mathrm{c}}$ \\
\hline 46 & $90.00^{\mathrm{bc}}$ & $95.44^{\mathrm{a}^{*}}$ \\
\hline 69 & $93.33^{\mathrm{ab}}$ & $96.78^{\mathrm{a}}$ \\
\hline 92 & $92.56^{\mathrm{ab}}$ & $97.00^{\mathrm{a}}$ \\
\hline
\end{tabular}

*Means not connected by the same letters are significantly different at alpha 0.05.

\subsubsection{Plant Height and Panicle Length}

Only $\mathrm{N}$ fertilizer rate caused significant effect in yield attributes. Both plowing frequency and compaction had not any significant effect on plant height and panicle length (Table 5).

Teff plants with higher plant height $(92 \mathrm{~cm})$ and panicle length $(38 \mathrm{~cm})$ were found by applying high amount $\mathrm{N}$ fertilizer ( $92 \mathrm{kgN} / \mathrm{ha})$ (Table 5). This is because high nitrogen usually favors vegetative growth of teff which results in taller teff plants heights having relatively greater panicle length. 


\subsubsection{Biomass Yield, Grain Yield and Harvest Index (HI)}

There were no significant differences among plowing frequencies in biomass yield, grain yield and harvest index of teff (Table 6). Though IAR (1998) as cited in Fufa et al. (2001), reported an increase in grain yield of teff with an increase plowing frequency, such report contradicts our present findings.

Table 5. Main effects of plowing frequency, compaction and N-fertilizer rates on plant height and panicle length.

\begin{tabular}{|l|l|l|}
\hline Factors & Plant height (cm) & Panicle length (cm) \\
\hline Plowing frequency & & \\
\hline 0nce & 79.63 & 34.27 \\
\hline Twice & 78.75 & 33.98 \\
\hline Thrice & 80.77 & 34.38 \\
\hline SE & 0.973 & 0.58 \\
\hline LSD & ns & ns \\
\hline CV (\%) & 5.39 & 7.46 \\
\hline compaction & & \\
\hline Non compacted & 79.05 & 34.85 \\
\hline Compacted & 80.38 & 33.68 \\
\hline SE & 0.793 & 0.47 \\
\hline LSD & $n s$ & $n s$ \\
\hline CV $\%)$ & 5.39 & 7.46 \\
\hline N-fertilizer rate & & \\
\hline $0 \mathrm{kgN} / \mathrm{ha}$ & $57.73^{\mathrm{d}}$ & $27.42^{\mathrm{d}}$ \\
\hline $46 \mathrm{kgN} / \mathrm{ha}$ & $81.82^{\mathrm{c}}$ & $35.10^{\mathrm{c}}$ \\
\hline $69 \mathrm{kgN} / \mathrm{ha}$ & $87.16^{\mathrm{b}}$ & $36.80^{\mathrm{b}}$ \\
\hline 92kgN/ha & $92.16^{\mathrm{a}^{*}}$ & $37.75^{\mathrm{a}}$ \\
\hline SE & 1.12 & 0.67 \\
\hline LSD & 1.58 & 0.95 \\
\hline CV $\%)$ & 5.39 & 7.46 \\
\hline
\end{tabular}

*Means not connected by the same letters are significantly different at alpha 0.05. 
Table 6. Main effects of plowing frequency, compaction and N-fertilizer rates on biomass yield, grain yield and harvest index.

\begin{tabular}{|c|c|c|c|}
\hline Factors & Biomass yield (kg/ha) & $\begin{array}{l}\begin{array}{l}\text { Grain } \\
\text { (kg/ha) }\end{array} \\
\end{array}$ & $\begin{array}{l}\text { Harvest Index } \\
\text { (HI) }\end{array}$ \\
\hline \multicolumn{4}{|c|}{ Plowing frequency } \\
\hline Once & 3726.67 & 1095.09 & 0.291 \\
\hline twice & 3753.80 & 1098.24 & 0.289 \\
\hline thrice & 4011.48 & 1206.30 & 0.300 \\
\hline $\mathrm{SE}$ & 108.64 & 37.14 & 0.004 \\
\hline LSD & ns & ns & ns \\
\hline CV (\%) & 13.23 & 15.15 & 6.00 \\
\hline \multicolumn{4}{|l|}{ compaction } \\
\hline Non compacted & $3450.679^{\mathrm{b}}$ & $1044.4^{\mathrm{b}}$ & 0.297 \\
\hline Compacted & $4210.617^{\mathrm{a}^{*}}$ & $1222^{\mathrm{a}}$ & 0.289 \\
\hline SE & 88.70 & 30.33 & 0.003 \\
\hline LSD & 125.40 & 42.89 & ns \\
\hline CV $(\%)$ & 13.23 & 15.15 & 6.00 \\
\hline \multicolumn{4}{|l|}{ N-fertilizer rate } \\
\hline $0 \mathrm{kgN} / \mathrm{ha}$ & $2368.27^{\mathrm{d}}$ & $665.8^{\mathrm{d}}$ & $0.279^{b}$ \\
\hline $46 \mathrm{kgN} / \mathrm{ha}$ & $3758.77^{\mathrm{c}}$ & $1120.6^{\mathrm{c}}$ & $0.298^{\mathrm{a}}$ \\
\hline $69 \mathrm{kgN} / \mathrm{ha}$ & $4471.48^{b}$ & $1358.5^{\mathrm{a}}$ & $0.304^{\mathrm{a}}$ \\
\hline $92 \mathrm{kgN} / \mathrm{ha}$ & $4724.07^{\mathrm{a}}$ & $1387.9^{\mathrm{a}}$ & $0.293^{\mathrm{ab}}$ \\
\hline SE & 125.44 & 42.89 & 0.005 \\
\hline LSD & 177.40 & 60.70 & 0.007 \\
\hline CV $(\%)$ & 13.23 & 15.15 & 6.00 \\
\hline
\end{tabular}

*Means not connected by the same letters are significantly different at alpha 0.05 .

There were significant differences between compacted and non-compacted plots in both biomass $(\mathrm{P}=0.0007)$ and grain yields $(\mathrm{P}=0.0035)$ but not of harvest index (Table 6). This agrees with research results from Chefe Donsa that a significant grain yield of teff was obtained from seedbed compaction (Fufa et al., 2001). Greater biomass (4211 kg/ha) and grain $(1222 \mathrm{~kg} / \mathrm{ha})$ yields were obtained from compacted plots than non-compacted plots. The reason for the high yield from compacted plots was due to early emergence and seedling growth as well as high teff ground cover.

Nitrogen fertilizer significantly $(\mathrm{P}=0.0001)$ improved biomass and grain yield in the control plots and harvest index $(\mathrm{P}=0.001)$ (Table 6). The biomass $(4,724 \mathrm{~kg} / \mathrm{ha})$ and grain $(1388 \mathrm{~kg} / \mathrm{ha})$ yields were obtained by applying $92 \mathrm{~kg} \mathrm{~N} / \mathrm{ha}$. However, greater harvest index (0.304) was obtained by applying $69 \mathrm{~kg} \mathrm{~N} / \mathrm{ha}$ which means that more grain yield per unit biomass was obtained from plots receiving this rate. 


\subsection{Partial Budget Analysis of N-Fertilizer rate}

The partial budget analysis indicates that high marginal rate of return (525\%) was obtained by applying $69 \mathrm{~kg} \mathrm{~N} / \mathrm{ha}$ (Table 7). This means that the income obtained by applying $69 \mathrm{~kg} \mathrm{~N} / \mathrm{ha}$ for teff was more than 5 times a unit total $\mathrm{N}$-fertilizer cost. It is also fair to farmers to use $46 \mathrm{~kg} \mathrm{~N} / \mathrm{ha}$ for it can bring comparable income which is more than 5 times total $\mathrm{N}$-fertilizer cost. The latter seems to support the nationally recommended $\mathrm{N}$-fertilizer rate for teff. This analysis is done by considering only grain yield of teff. If we add the value of the straw, the return will become more than the already estimated income.

Table 7. Partial budget analysis for $\mathrm{N}$-fertilizer rates.

\begin{tabular}{|c|c|c|c|c|}
\hline \multirow[t]{2}{*}{ Total cost and total income } & \multicolumn{4}{|c|}{$N$-fertilizer rates $\left(N_{i}\right)$} \\
\hline & $0 \mathrm{kgN} / \mathrm{ha}$ & $46 \mathrm{kgN} / \mathrm{ha}$ & $69 \mathrm{kgN} / \mathrm{ha}$ & 92kgN/ha \\
\hline \multicolumn{5}{|l|}{ Cost } \\
\hline \multicolumn{5}{|l|}{ 1. Labor cost } \\
\hline - Fertilizer weighing and taking to field & 0.00 & 30.00 & 30.00 & 30.00 \\
\hline - Fertilizer Application & 0.00 & 30.00 & 30.00 & 30.00 \\
\hline 2. Fertilizer cost & 0.00 & 400.00 & 600.00 & 800.00 \\
\hline Total cost (Tc) & 0.00 & 460.00 & 660.00 & 860.00 \\
\hline \multicolumn{5}{|l|}{ Income } \\
\hline Economic (grain) yield (kg/ha) & 666 & 1121 & 1359 & 1388 \\
\hline Income (birr/ha) & 3330 & 5605 & 6795 & 6940 \\
\hline Change in cost $(\Delta C)$ & 0.00 & 460 & 660 & 860 \\
\hline Change in income $(\Delta \mathrm{I})$ & 0.00 & 2275 & 3465 & 3610 \\
\hline $\begin{array}{l}\text { Marginal Rate of Return (MRR = } \\
(\Delta I) /(\Delta C) * 100)\end{array}$ & 0.00 & $494.6 \%$ & $525 \%$ & $419.8 \%$ \\
\hline
\end{tabular}

Where,

1. $\Delta \mathrm{C}=$ cost of each rate subtracted

from cost of the control

2. $\Delta \mathrm{I}=$ income of each rate $(\mathrm{Birr} / \mathrm{ha})$

subtracted from the income of control

3. Labor costs were calculated by assuming 15birr/labor/day

Mekelle University 
4. Incomes were calculated by assuming $500 \mathrm{birr} / 100 \mathrm{~kg}$ of teff.

\section{CONCLUSION AND RECOMMENDATION}

Plowing frequency did not affect most of the yield and yield attributes of teff. However, it affected tillering of teff when combined with compaction. Incidentally, this factor alone did not increase the number of tillers per plant. Generally, frequent plowing is not a major factor to increase teff productivity on Vertisols, but it is important to control weeds.

Compaction resulted in low tillering but high ground cover. This means compaction did not favor tillering of teff but it encourages ground cover. Interaction between compaction and $\mathrm{N}$ also influenced tillering and ground cover of teff. Optimum returns were found from biomass and grain yields on compacted plots. The overall outcome of compaction is that it affects teff productivity on vertisols.

Nitrogen encourages ground cover with the application of $69 \mathrm{~kg} \mathrm{~N} / \mathrm{ha}$. High rate of nitrogen $(92 \mathrm{~kg} \mathrm{~N} / \mathrm{ha}$ ) resulted in taller plants with relatively longer panicles and greater average biomass and grain yields. The partial budget analysis shows that application of $69 \mathrm{~kg} \mathrm{~N} / \mathrm{ha}$ can bring an income which is more than five times the cost of $\mathrm{N}$-fertilizer. Farmers should not plow their land more than three times as more frequent plowing do not enhance teff productivity on Vertisols. Plowing three times is appropriate for weed control. Compaction contributes to teff productivity by facilitating good seed-soil contact on Vertisols hence, farmers should be encouraged to practice it.

Application of $69 \mathrm{~kg} \mathrm{~N} / \mathrm{ha}$ gave optimum biomass and grain yields of teff and hence farmers have to use this rate for teff production on Vertisols. As an alternative, farmers can also use $46 \mathrm{kgN} / \mathrm{ha}$ to get comparable income from the crop on Vertisols. Generally, this implies that farmers can apply $\mathrm{N}$-fertilizers at a rate ranging from $46-69 \mathrm{~kg} \mathrm{~N} / \mathrm{ha}$ to get optimum teff yield on vertisols.

\section{REFERENCES}

Deckers, J.A., Nachtergaele, F.O. \& Spaargaren, O.C. (Eds.). 1998. World Reference Base for Soil Resource: Introduction. Acco Leuven/Amersfoort. Belgium, pp.165.

DZARC (Debre Zeit Agricultural Research Centre). 1989. Annual research progress report for 1988/89. Debre Zeit, Ethiopia. 
Ehlers, W., Popke, V., Hesse, F. \& Bohm, W. 1983. Penetration Resistance and Root Growth of Oats in Tilled and Untilled Loam Soil. Soil Tillage Research, 3:261-275.

Fleischer, J.E., Barnes, A.R. \& Awubila, B. 1989. Grain Yield and Nutritive Value of Crop Residues from three Varieties of Maize (Zea Mays L.) crop. In: A. N. Said and B.H. Dzowela (Eds.), Overcoming Constraints to Efficient Utilization of Agricultural Byproducts as Animal Feed. Proceedings of the 4th annual workshop held at the Institute of Animal Research. Mankon Station, Bameda, Cameroon, 20-27 October, 1987, Africa Research Network for Agricultural by-products (ARNAB), Addis Ababa, Ethiopia. pp. 239-255.

Fufa Hundera., Tesfaye Bogale., Hailu Tefera., Kebebew Asefa., Tiruneh Kefyalew., Abbera Debelo \& Seifu Ketema. 2001. Agronomy Research in Teff. In: Hailu Tefera, Getachew Belay \& M. Sorrels (eds.), Narrowing the Rift: Teff Research and Development. Ethiopian Agricultural Research Organization (EARO), Addis Ababa, Ethiopia, pp.167176.

IAR. 1998. Holleta Agricultural Research Center, progress report for the period April 1997 to March 1998. IAR, Addis Ababa, Ethiopia.

Ishaq, M., Ibrahim, M., Hassan, A., Saeed, M. \& Lal, R. 2001. Sub-soil Compaction Effects on Crops in Punjab Pakistan. II. Root Growth and Nutrient Uptake of Wheat and Sorghum. Soil Tillage Research, 60:153-161.

Kebede, H., Johnson, R.C. \& Frris, D.M. 1989. Photohsynthetic Response of Eragrostis tef. to Temperature. Physiol. Plant, 77:262-266.

Kenea Yadeta, Getachew Ayele \& Workneh Negatu. 2001. Farming Research on Teff: Small Holders Production Practices. In: Hailu Tefera, Getachew Belay and M. Sorrels (eds.), Narrowing the Rift: Teff Research and Development. Ethiopian Agricultural Research Organization (EARO), Addis Ababa, Ethiopia, pp.9-23.

Melesse Temesgen. 2007. Conservation Tillage Systems and Water Productivity Implications for Small Holder Farmers in Semi-Arid Ethiopia. PhD dissertation, Delft University of Technology, The Netherlands.

Nicole, D.J. 1999. Teff and Fingermillet: Archaeobotanical Studies of two Indigenous East African Cereals. Master thesis. Simon Fraser University. 
Nyssen, J., Poesen, J., Mitiku Haile, Moeyersons, J. \& Deckers, J. 2000. Tillage erosion on slopes with soil conservation structures in the Ethiopian highlands. Soil and Tillage Research, 57(3): 115-127.

Oussible, M., Crookstone, P.K. \& Larson, W.E. 1992. Sub-surface Compaction Reduces the Root and Shoot Growth and Grain of Wheat. Agron. J., 84:34-38.

Taddesse Ebba. 1969. Tef (Eragrostis tef): the cultivation, usage and some of the Known Diseases and Insect Pests. Part-2. Debre Zeit Agricultural Research Station. Bulletin no. 60, Haile Slassie I University, College of Agriculture, Dire Dawa, Ethiopia.

Tadesse, D. 1993. Study on Genetic Variation of Landraces of Teff (Eragrostis tef(Zucc.) Trotter) in Ethiopia. Genetic Resources and Crop Ewfutim, 40: 10 1-104.

Tarekegne, A., Gebre, A., Tanner, D. G. \& Mandefro, C. 1996. Effect of Tillage Systems and Fertilizer Levels on Continous Wheat Production in Central Ethiopia. In: D. G, Tanner., T. S. Payne \& O. S. Abdalla (eds.), The Ninth Regional Wheat Workshop for Eastern, Central and Southern Africa, Addis Ababa, Ethiopia, CIMMYT, pp.56-63.

Tigray Agricultural Research Institute (TARI). 2007. Axum Agricultural Research Center. Progress report for the period from February 2006 to December 2007. 